\title{
Regulators pull contract for chemical review
}

When US government regulators hired the firm Sciences International to help review a potentially dangerous chemical, they almost certainly didn't intend to ignite a political firestorm.

But the company's links to the chemical industry have enraged environmentalists and forced the National Institute of Environmental Health Sciences (NIEHS) to pull the contract. Last week, in the face of growing pressure from both Congress and the public, the agency announced that it would rereview the 20 chemicals that the company had been involved in studying.

Scientists, environmental groups and even private contractors say that the situation highlights a weakness in federal environmental and health regulation. Private companies hired to do risk assessments are rarely required to disclose conflicts of interest. And often, the companies have relationships with the industries that the regulators are charged with overseeing. "It is definitely a problem," says Sandra Schubert, director of government affairs for the Environmental Working Group, the watchdog based in Washington DC that criticized the work.

The review involves bisphenol A, a chemical commonly found in plastics, including baby bottles and microwave containers. The chemical disrupts the endocrine system in mice, and some researchers think that it might cause similar effects in humans. Both Japanese and European regulators say that more research is needed to determine whether the chemical is harmful.

In July 2005, the NIEHS hired Sciences International of Alexandria, Virginia, as part of a panel to summarize hundreds of studies on bisphenol A. The firm had done the same sort of work many times before for the agency. But this time, the Environmental Working Group caught wind of the study and learned that Sciences International had two clients - Dow Chemical and BASF that produce bisphenol A. In late February, the advocacy group wrote to the agency demanding a review of Sciences International's role in the study. After several weeks of mounting pressure, the NIEHS announced that it was scrapping its contract and reviewing the work already done on bisphenol A and the other chemicals.

Several scientists involved in the review told Nature they think Sciences International had behaved ethically and impartially. "I really don't

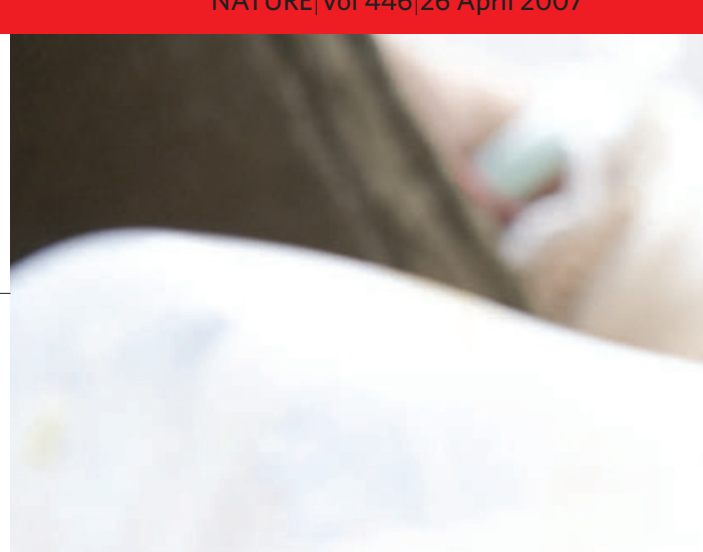

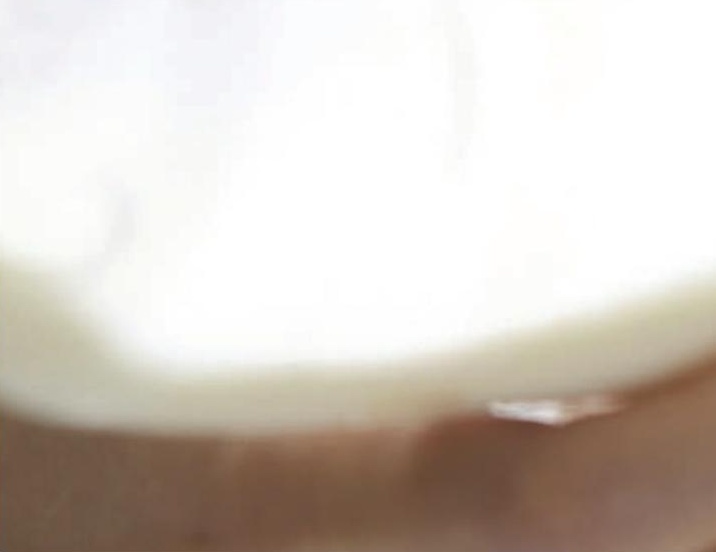

think that they were trying to influence the process," says Simon Hayward, a cancer biologist at Vanderbilt University in Nashville, Tennessee.

But others contend that the company was deliberately stacking the review literature in favour of industry. "All those reports are suspect," says Frederick vom Saal, an endocrinologist at the University of Missouri at Columbia, who was not involved in the review. "The panel should be shut down."

Independent scientists on the bisphenol-A panel were required to sign conflict-of-interest forms, but Sciences International was not. The

\section{Online resources threaten livelihood of libraries}

The closure of five of the 26 regional libraries of the US Environmental Protection Agency (EPA) last year sparked international protest. Congressional hearings were held, and a government investigation was launched. In February this year, the president of the American Library Association told Congress that the closures have restricted access to information in at least 31 states.

The EPA is not alone - last year, the Department of Energy closed its headquarters library in Washington DC. And now, NASA is considering downsizing its network of libraries - including the one at its leading science-research centre, the Goddard Space Flight Center in Greenbelt, Maryland.
Tight budgets could bring even more whittling of libraries in the United States. "When budgets are threatened, agencies tend to say let's put the library on the chopping block," says Tara Olivero, assistant director at the American Library Association in Washington DC.

Libraries are already working to reinvent themselves in a digital world in which online access is fast reducing the need for rows of books and stacks of journals. But a full transition to electronic resources might not save money as agencies hope.

Officials at the EPA, whose libraries provide a wide range of information about environmental protection and management, initially cited a proposed budget cut of US $\$ 2$ million - an $80 \%$ drop from the previous year - as the main reason for downsizing its library network. Yet critics point out that internal EPA studies have suggested that having a librarian saves between $\$ 3$ and $\$ 7$ in professional staff time for every dollar invested. Since the closures, EPA librarians have struggled to maintain the same level of cost effectiveness. On requesting a publication from another library, they are sometimes told that the item is not available and that no one

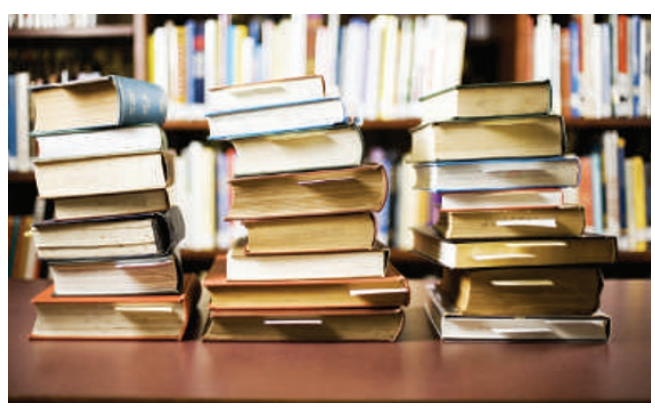

Replacing books with electronic resources may not save money. 
